\title{
Trophic compensation stabilizes marine primary producers exposed to artificial light at night
}

\author{
E. Maggi* ${ }^{*}$ L. Benedetti-Cecchi \\ Dipartimento di Biologia, CoNISMa, Università di Pisa, via Derna 1, 56126 Pisa, Italy
}

\begin{abstract}
Artificial light at night (ALAN) is a widespread phenomenon along coastal areas. Despite increasing evidence of pervasive effects of ALAN on patterns of species distribution and abundance, the potential of this emerging threat to alter ecological processes in marine ecosystems has remained largely unexplored. Here, we show how exposure to white LED lighting, comparable to that experienced along local urbanized coasts, significantly enhanced the impact of grazing gastropods on epilithic microphytobenthos (MPB). ALAN increased both the photosynthetic biomass of MPB and the grazing pressure of gastropods, such that consumers compensated for the positive effect of night lighting on primary producers. Our results indicate that trophic interactions can provide a stabilizing compensatory mechanism against ALAN effects in natural food webs.
\end{abstract}

KEY WORDS: Compensatory dynamics $\cdot$ Light pollution · ALAN · Trophic interactions · Marine food webs

\section{INTRODUCTION}

Distribution of artificial light at night (ALAN) is increasing at global scale (Falchi et al. 2016), posing questions about its potential role as a global threat to biodiversity (Davies \& Smyth 2017). Coastal areas are among the most impacted zones, with more than $20 \%$ of the world's coastlines experiencing high levels of ALAN due to the presence of human settlements (Davies et al. 2014). Potential impacts are expected to grow with advances in technology, as popularity and use of LED lighting is rising (Gaston et al. 2012).

\footnotetext{
*Corresponding author: emaggi@biologia.unipi.it
}

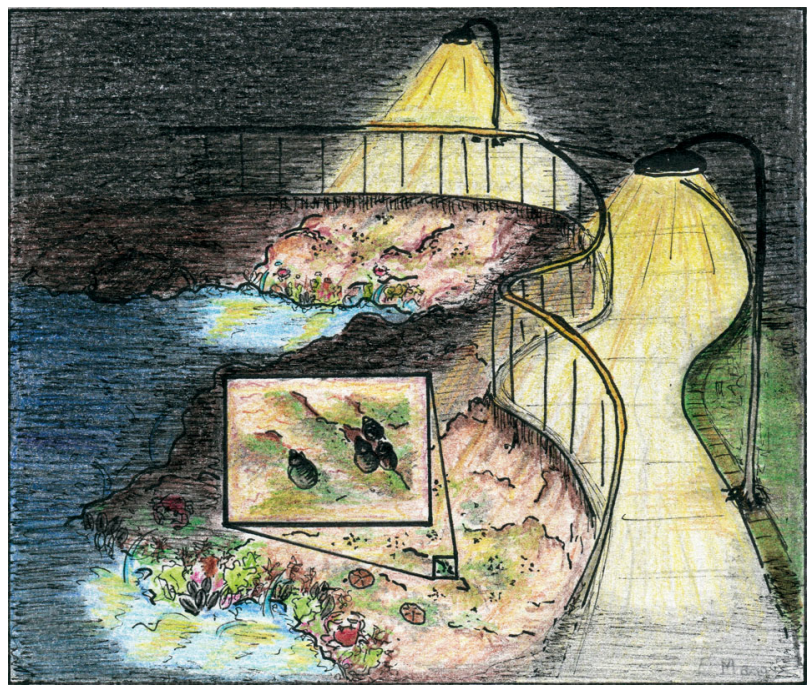

Trophic interactions between gastropods and epilithic microphytobenthos can provide a stabilizing compensatory mechanism against effects of artificial light at night on rocky shores.

Painting: Elena Maggi

The light/dark cycle regulates the physiology and behavior of many organisms, including reproduction and migration. It is therefore not surprising that the global trend of increasing ALAN is having profound impacts on many species (e.g. bats, birds and insects) (Spoelstra et al. 2015, Knop et al. 2017). The few studies performed on plants confirm that relatively low levels or short durations of light can be effective in influencing growth and reproduction of terrestrial autotrophs (Bennie et al. 2015, 2018, ffrenchConstant et al. 2016). Effects of ALAN on whole ecosystems and services they provide, however, are still far from being elucidated. Recent research accumu-

(C) The authors 2018. Open Access under Creative Commons by Attribution Licence. Use, distribution and reproduction are unrestricted. Authors and original publication must be credited. 
lated evidence that effects can cascade from one species to other organisms and even habitats (Manfrin et al. 2017, Bennie et al. 2018, Sanders et al. 2018), but still many questions remain unanswered. Of particular concern are the little explored effects of ALAN on ecological processes in marine coastal environments, which are already experiencing a wide range of anthropogenic stressors (Davies et al. 2014). The few previous studies on coastal systems evidenced effects of ALAN on colonization and behavior of invertebrate and fish assemblages (Davies et al. 2015, Navarro-Barranco \& Hughes 2015, Bolton et al. 2017), while almost neglecting the possible effects on primary producers. By disrupting natural light/dark cycles, ALAN is expected to influence primary producers either directly (through photosynthetic activity and cell growth; see Jacquet et al. 2001) or indirectly through its effect on grazing pressure. Here, we provide an experimental test of these hypotheses by manipulating nighttime artificial lighting and gastropod grazers in a rocky intertidal food web, where microphytobenthos (MPB) covering rock surfaces represents the main fraction of biomass produced and a key food resource for grazers (Underwood et al. 2017).

\section{MATERIALS AND METHODS}

The study was carried out on a rocky coast south of La Spezia (Italy, Western Mediterranean Sea; $43^{\circ} 28^{\prime} 02^{\prime \prime} \mathrm{N}, 10^{\circ} 22^{\prime} 19^{\prime \prime} \mathrm{E}$ ), within a limited access area owned by the Italian Navy. High-shore assemblages (0.2-0.4 m above mean low water level) are dominated by MPB (mostly cyanobacteria) and by the small littorinid snail grazer Melarhaphe neritoides (Linné), which is mainly active under moist conditions (Dal Bello et al. 2017). Due to the limited amplitude of tides, these assemblages are usually above the sea level and wetted only during sea storms or rain events (Dal Bello et al. 2017, Maggi et al. 2017).

\section{Experimental design and sampling}

In November 2016, we selected 4 sites 5-10 m in horizontal extent and 30-40 m apart. Sites were characterized by a night sky brightness of $20.14( \pm 0.02 \mathrm{SE}$ ) mag $\operatorname{arcsec}^{-2}$ (magnitude per square arc second, measured through a Sky Quality Meter L [Unihedron], during a new moon phase and corresponding to a relatively dark sky). Two sites were randomly allocated to the lit treatment and 2 served as controls (lit and unlit sites, respectively). ALAN was simulated with a cool white LED lamp (Labcraft, $12.5 \mathrm{~W}$ ), mounted on a vertical stainless steel pole secured to the rock, high on the shore at each lit site. Light was automatically switched on at dusk and off at dawn. Lit and unlit sites were distant enough to ensure that artificial lighting did not influence control sites. At each site, we randomly selected 6 quadrats $(10 \times 10 \mathrm{~cm})$ that were scraped clean with a chisel mounted on a battery drill to initiate succession. Quadrats were evenly and randomly allocated to 2 levels of factor 'Herbivore' (control and exclusion). Access of snails to exclusion quadrats was prevented by applying an organic glue along the entire perimeter (Tree Tanglefoot, pesticide-free). To check for possible artefacts, additional quadrats were established at each site where the glue was applied discontinuously along the margins to allow the access of snails (procedural control). Due to the topographic complexity of the substratum and the limited area affected by the lamp, we could allocate only 2 replicates to this treatment. To estimate short-term effects of manipulated factors, the experiment was sampled after $26 \mathrm{~d}$. MPB photosynthetic biomass and maximum photosynthetic efficiency were estimated for each quadrat by averaging, respectively, 2 replicate values of minimum fluorescence $\left(F_{0}\right)$ and effective quantum yield of photosystem II (calculated as: $\left[F_{\mathrm{m}}-F_{\mathrm{o}}\right] / F_{\mathrm{m} i} F_{\mathrm{m}}=$ maximum fluorescence). Measurements were conducted in the morning after a dark adaptation period of 5 min using an underwater fluorometer (DIVING-PAM, WALZ) (Maggi et al. 2015). Densities of snails were estimated on a per plot basis; frequent visits confirmed that the glue effectively excluded these grazers. Other grazers are virtually absent in the high-shore habitat where MPB develops.

\section{Data analyses}

Data of MPB photosynthetic biomass and maximum photosynthetic efficiency and density of snails were analysed by means of a 3-factor ANOVA, with Site (random, 2 levels) nested within Light (fixed, lit vs. unlit) and both crossed with Herbivore (fixed, control vs. exclusion). Data from procedural controls were visually contrasted with those from controls and exclusions. Heterogeneity of variances was checked through Cochran's test and data transformed if necessary $(\ln [\mathrm{x}+1])$. A posteriori contrasts were performed through Student-Newman-Keuls (SNK) tests. 

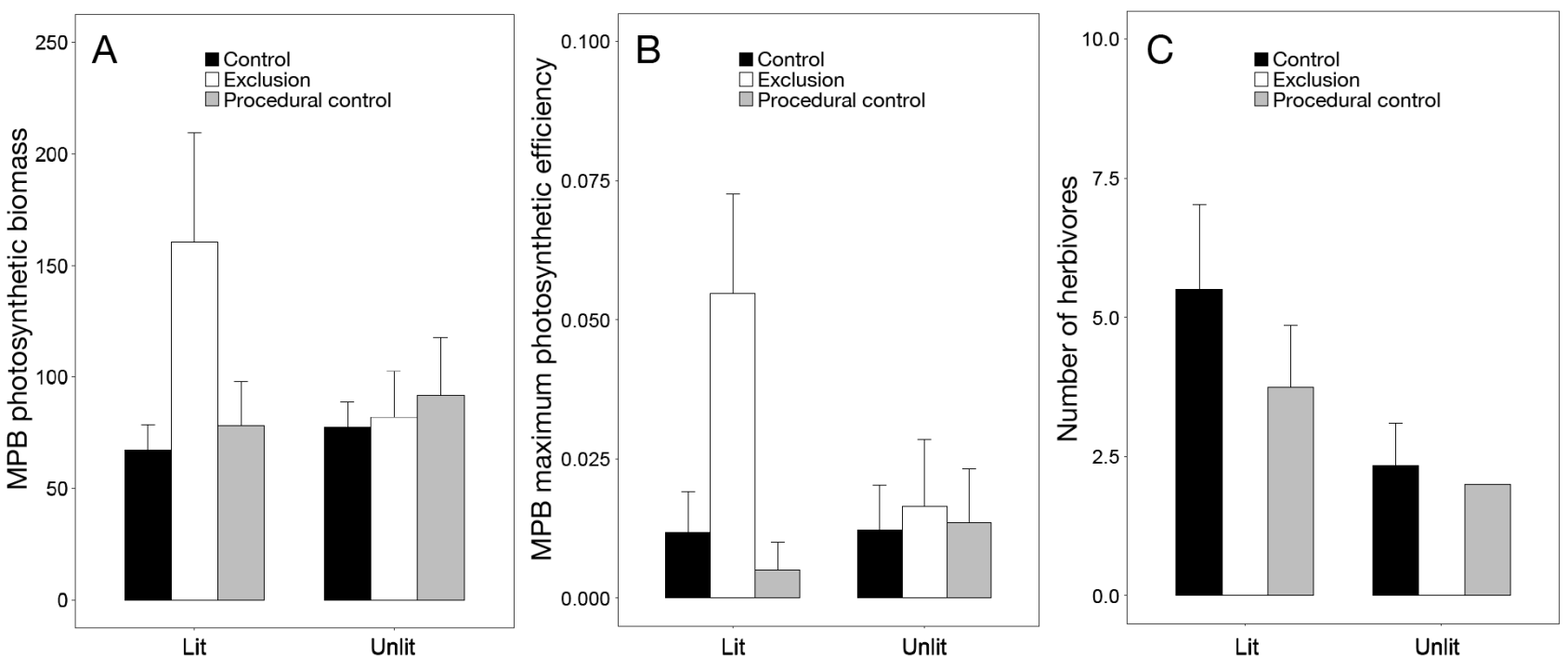

Fig. 1. Impact of cool white LED lighting on the herbivore-resource relationship between microphytobenthos (MPB) colonizing cleared substrata and the littorinid snail grazer Melarhaphe neritoides. Mean values (+1 SE) of (A) MPB photosynthetic biomass $\left(F_{0}\right),(B)$ MPB maximum photosynthetic efficiency (Yield). Note that values in $(\mathrm{A})$ are given in arbitrary units and values in (B) are unitless. (C) Number of individulas of $M$. neritoides; $\mathrm{n}=6$ for control and exclusion, $\mathrm{n}=4$ for procedural control. Note that the exclusion treatment was effective in preventing any snail from entering the plot

Analyses were run in R v3.4.3 (GAD package; R Core Team 2017). The dataset supporting this article is available in the Supplement at www.int-res.com/ articles/suppl/m606p001_supp.xlsx.

\section{RESULTS}

Photosynthetic biomass of MPB was significantly larger in herbivore-exclusion plots than in the other treatments at lit sites, whereas herbivores had no detectable effect at unlit sites (Light $\times$ Herbivores: $F_{1,2}=62.64, \mathrm{p}<0.05$ ) (Fig. 1A). Maximum photosynthetic efficiency showed a similar pattern, although the statistical test of the interaction indicates that it was not significant at $\alpha=5 \%\left(F_{1,2}=12.88,0.05<\mathrm{p}<\right.$ 0.1 ) (Fig. 1B). The exclusion treatment was effective in reducing density of $M$. neritoides (Site[Light] $\times$ Herbivore: $F_{2,16}=4.15, \mathrm{p}<0.05$; SNK tests: control $>$ exclusion at all sites). ALAN did not significantly affect density of $M$. neritoides, despite a trend towards a larger density of $M$. neritoides at lit than at unlit sites (Fig. 1C).

Night sky brightness was lower at lit than at unlit sites (lit $=13.235 \pm 0.62 \mathrm{mag} \operatorname{arcsec}^{-2}$; unlit $=20.325 \pm$ $0.14 \mathrm{mag} \operatorname{arcsec}^{-2}$ ). Values recorded at lit sites were within the range of those collected along lit coasts of Tuscany during the study period $(13.39 \pm 3.51 \mathrm{mag}$ $\operatorname{arcsec}^{-2}$ ).

\section{DISCUSSION}

Our experiment provides direct field evidence that ALAN can alter trophic interactions in a marine food web. Coastal areas host highly productive ecosystems, mostly due to the activity of microscopic organisms such as MPB (Chavez et al. 2011). Nevertheless, the high rate of urban development in these areas is expanding the number of stressors affecting ecosystem processes; among potential sources of disturbance, the scientific community recently re-evaluated the role of night light pollution as a focus for global change research (Davies \& Smyth 2017). Intertidal and shallow subtidal habitats, in particular, are those most likely exposed to intensities and spectra of artificial light able to interfere with biological regulation by circadian rhythms or moon phases. Our results show that cool white LED lighting, comparable to that experienced along local urbanized coasts, can influence both primary producers and their consumers in rocky-shore habitats during the early colonization process. We observed a simultaneous increase in MPB photosynthetic biomass and maximum efficiency only at lit sites where littorinid snails had been excluded. This result indicates that ALAN can positively influence photosynthetic activity and cell growth of microscopic primary producers. This is in agreement with past observations on strains of the marine oxyphotobacteria Prochlorococcus, whose cell cycle is 
regulated by light and positively influenced by continuous high irradiance values (Jacquet et al. 2001). Lack of a similar increase in MPB biomass at unlit sites and in the presence of herbivores under lit conditions, however, indicates that ALAN also increased grazing pressure in the short term during succession. Under unlit conditions, rates of consumption by grazers were likely balanced by positive effects on biofilm growth rates caused by snail excretions as well as removal of dead cells (which may result in an increase in nutrient and light availability; Skov et al. 2010). Increased light availability at lit sites, conversely, enhanced the performance of biofilms, but only in the absence of grazers. The fact that the biomass and the photosynthetic efficiency of biofilms were very similar under lit and unlit conditions when littorinids were present indicates that these grazers were able to compensate for the direct positive effect of ALAN on biofilms that was observed in exclusion quadrats. One explanation for this compensatory effect is that ALAN increased the metabolism and grazing efficiency of grazers without affecting their density. However, although not significant, a trend towards a larger abundance of littorinids in the lit treatment was evident, suggesting that night-time lightning may attract these grazers either directly or indirectly through increased resources availability. These explanations are not mutually exclusive, because continuous exposure to light might alter the metabolic demand of grazers and thus their mobility (Bolton et al. 2017).

Night light pollution represents one of the most widespread sources of stress on ecosystems (Davies \& Smyth 2017). Knowledge of biological and ecological effects of ALAN is rapidly growing, but impacts on marine coastal ecosystems are still underexplored. Recent studies revealed effects on predatorprey interactions including invertebrates and fish, due to influences on their behavior (Bolton et al. 2017, Underwood et al. 2017). Here, we report the first evidence of alteration in herbivore-resource relationships in marine assemblages, due to direct and indirect effects of ALAN. Although further research is needed to elucidate the role of physiological and behavioral mechanisms, our findings indicate that effects of terrestrial lighting are largely detectable on marine coastal organisms through either physiological effects or behavioral changes. This is of major importance, as effects of ALAN might interact with those of other local or global drivers of change along coastal urbanized areas, such as increases in mean and extreme temperatures, eutrophication, hypoxia and species invasion (Davies \& Smyth 2017). However, marine food webs are complex systems where compensatory mechanisms may confer resilience to multiple threats, through adjustments in the strength of pre-existing processes (Connell \& Ghedini 2015, Ghedini et al. 2015, Goldenberg et al. 2018). Our results show how grazing can compensate for positive ALAN effects on primary producers, extending the stabilizing effect of trophic interactions to this emerging threat. To what extent compensating trophic interactions will buffer marine food webs against escalating ALAN impacts along coastlines remains to be determined.

Acknowledgements. This work was supported by the University of Pisa under project PRA_2017_19. We are grateful to the Marina Militare 'La Spezia' and Mar. F. Brogi for allowing access to the experimental site at Maralunga. We thank M. Nardini and C. Mintrone for help with the field work and A. Giacomelli for contributing equipment and knowledge for measuring light pollution.

\section{LITERATURE CITED}

Bennie J, Davies TW, Cruse D, Inger R, Gaston KJ (2015) Cascading effects of artificial light at night: resourcemediated control of herbivores in a grassland ecosystem. Philos Trans R Soc B 370:20140131

Bennie J, Davies TW, Cruse D, Inger R, Gaston KJ (2018) Artificial light at night causes top-down and bottom-up trophic effects on invertebrate populations. J Appl Ecol 55:2698-2706

Bolton D, Mayer-Pinto M, Clark GF, Dafforn KA, Brassil WA, Becker A, Johnston EL (2017) Coastal urban lighting has ecological consequences for multiple trophic levels under the sea. Sci Total Environ 576:1-9

Chavez FP, Messie M, Pennington JT (2011) Marine primary production in relation to climate variability and change. Annu Rev Mar Sci 3:227-260

Connell SD, Ghedini G (2015) Resisting regime shifts: the stabilizing effect of compensatory dynamics. Trends Ecol Evol 30:513-515

Dal Bello M, Rindi L, Benedetti-Cecchi L (2017) Legacy effects and memory loss: how contingencies moderate the response of rocky intertidal biofilms to present and past extreme events. Glob Change Biol 23:3259-3268

Davies TW, Smyth T (2017) Why artificial light at night should be a focus for global change research in the 21st century. Glob Change Biol 24:872-882

Davies TW, Duffy JP, Bennie J, Gaston KJ (2014) The nature, extent, and ecological implications of marine light pollution. Front Ecol Environ 12:347-355

Davies TW, Coleman M, Griffith KM, Jenkins SR (2015) Night-time lighting alters the composition of marine epifaunal communities. Biol Lett 11:20150080

Falchi F, Cinzano P, Duriscoe D, Kyba CCM and others (2016) The new world atlas of artificial night sky brightness. Sci Adv 2:e1600377

ffrench-Constant RH, Somers-Yeates R, Bennie J, Economou T, Hodgson D, Spalding A, McGregor PK (2016) Light pollution is associated with earlier tree budburst across the United Kingdom. Proc R Soc B 283:20160813 
Gaston KJ, Davies TW, Bennie J, Hopkins J (2012) Reducing the ecological consequences of night-time light pollution: options and developments. J Appl Ecol 49:1256-1266

Ghedini G, Russel BD, Connell SD (2015) Trophic compensation reinforces resistance: herbivory absorbs the increasing effects of multiple disturbances. Ecol Lett 18:182-187

Goldenberg SU, Nagelkerken I, Marangon E, Bonnet A, Ferreira CM, Connell SD (2018) Ecological complexity buffers the impacts of future climate on marine consumers. Nat Clim Chang 8:229-233

Jacquet S, Partensky F, Marie D, Casotti R, Vaulot D (2001) Cell cycle regulation by light in Prochlorococcus strains. Appl Environ Microbiol 67:782-790

Knop E, Zoller L, Ryser R, Erpe CG, Hörler M, Fontaine C (2017) Artificial light at night as a new threat to pollination. Nature 548:206-209

Maggi E, Milazzo M, Graziano M, Chemello R, BenedettiCecchi L (2015) Latitudinal- and local-scale variations in a rocky intertidal interaction web. Mar Ecol Prog Ser 534: 39-48

Maggi E, Rindi L, Dal Bello M, Fontanini D, Capocchi A, Bongiorni L, Benedetti-Cecchi L (2017) Spatio-temporal variability in Mediterranean rocky shore microphytobenthos. Mar Ecol Prog Ser 575:17-29

Manfrin A, Singer G, Larsen S, Weiß N and others (2017) Artificial light at night affects organism flux across eco-

Editorial responsibility: Antony Underwood,

Sydney, New South Wales, Australia system boundaries and drives community structure in the recipient ecosystem. Front Environ Sci 5:61

*Navarro-Barranco C, Hughes LE (2015) Effects of light pollution on the emergent fauna of shallow marine ecosystems: amphipods as a case study. Mar Pollut Bull 94: 235-240

R Core Team (2017) R: a language and environment for statistical computing. R Foundation for Statistical Computing, Vienna. www.r-project.org

Sanders D, Kehoe R, Cruse D, van Veen FJF, Gaston KJ (2018) Low levels of artificial light at night strengthen top-down control in insect food web. Curr Biol 28: 2474-2478

Skov MW, Volkelt-Igoe M, Hawkins SJ, Jesus B, Thompson RC, Doncaster CP (2010) Past and present grazing boosts the photo-autotrophic biomass of biofilms. Mar Ecol Prog Ser 401:101-111

Spoelstra K, van Grunsven RHA, Donners M, Gienapp P and others (2015) Experimental illumination of natural habitat-an experimental set-up to assess the direct and indirect ecological consequences of artificial light of different spectral composition. Philos Trans R Soc B 370: 20140129

*Underwood CN, Davies TW, Queirós AM (2017) Artificial light at night alters trophic interactions of intertidal invertebrates. J Anim Ecol 86:781-789

Submitted: July 18, 2018; Accepted: October 1, 2018

Proofs received from author(s): November 5, 2018 